\title{
AFFECTIVE DOMAIN DEVELOPMENT: REALITY AND EXPECTATION
}

\author{
Sugirin \\ FBS Universitas Negeri Yogyakarta (e-mail: sugirin@uny.ac.id; \\ HP: 08122781479)
}

\begin{abstract}
Abstrak: Pengembangan Ranah Afektif: Kenyataan dan Harapan. Pendidik masa kini mendambakan perhatian yang seimbang terhadap pengembangan ranah kognitif, psikomotorik dan afektif dalam mendidik generasi muda. Namun, di dalam pelaksanaannya sedikit sekali penghargaan yang diberikan kepada anak-anak yang telah menunjukkan perkembangan ranah afektif secara baik. Hal ini terjadi karena tolok ukur keberhasilan pendidikan selalu mengacu kepada prestasi siswa yang terkait dengan ranah kognitif atau psikomotorik. Selain itu, banyak contoh ambivalensi dalam kehidupan nyata di masyarakat yang dapat melemahkan pondasi bagi pengembangan ranah afektif. Apabila generasi muda diharapkan berkembang menjadi manusia seutuhnya, penghargaan yang layak seharusnya diberikan kepada mereka yang berhasil dalam mengembangkan ranah afektifnya, dan harus ada teladan yang dapat mereka acu. Selain itu, pendampingan perlu dilakukan oleh orang tua dan guru.
\end{abstract}

Kata kunci : pengembangan ranah afektif, penghargaan, teladan, pendampingan

\section{INTRODUCTION}

In Indonesia, where people constantly watch and hear preaches live in mosques and churches, or on television almost every day, affection should develop accordingly in the heart of every individual. Honesty, justice,empathy, selfsacrifice, dedication, tolerance, peace and harmony, should dominate the day-to-day life of the Indonesian community. In reality, however, corruptions flourish throughout the country, legal abuses are parts of day-to-day news hits, fights between local residents happen repeatedly, children abuses and sexual harassments are frequently reported. Drug abuses, which were initially known only among the children of the middle or high class, are now penetrating those of the low social class as well.Clasheshappen sporadically among school children from the same or different schools, between residents of the neighboring villages, and between incumbents of different political parties or supporters of different candidates in the election of governors or regents. There should be no son killing his own father and no father raping his own daughter, and so forth. However, in reality, crimes and misbehaviors are frequently reported to happen in the Indonesian territory.

In Australia, where people do not talk much about religion and morality, affection has been part of day-to-day 
life at school and in the community. Respecting elders, helping the weak, giving priority to women and the handicapped are not slogans. They are living practices that have become parts of the property of the life of the Australian people. On the public transports, for example, the young would feel guilty if they did not give way the seat to the elders, the women, or the handicapped.

It is in Australia that one can still witness what the "dhalang" (a puppeteer in a Javanese shadow play) says about the peace and welfare blessed to the country narrated in the first episode of the story. In an Australian farm, the farmer only needs to open the gate of the shed in the morning and the cattle will leave, graze on the grassland, and return to the shed in the late afternoon. The farmer does not have to worry about thieves, because there are no thieves who will steal the cattle. In the District of Blackburn, about four kilometers away from Deakin University Melbourne campus, some families do not bother about locking the doors to their house or garage, because they have no doubt about the security of their district. The policemen do their round patrolling in the area once in a while, but they do not usually stay long. The police do not usually stand around the crossroads in the cities of Melbourne or Sydney, but drivers and motorists do not speed through the red light. The hidden camera might be the answer, but the discipline of the people might be the more accurate reason. Then, what is wrong with what happens in Indonesia?
In every city in Indonesia, there are almost always policemen standing around every crossroad and busy spot, but speeding through the red light or other violations of traffic regulations are common. When traffic offenders are caught, there does not seem to be any clearly standardized measure which guarantees that the same offence will not be repeated for the second time.

These two contradictory scenes have prompted the writer to further explore what lie behind the scenes and to offer solution to the problems surrounding the development of the affective domains in the Indonesian education by adapting models existing both in the domestic and overseas settings. This discussion may, to some extent, encompass aspects of character education. The choice for the focus on "affective domain development" is meant to be more universal in order to enable comparison of the same aspects within different cultures. While some elements of character education are culturally bound to specific localities, races, or nations, affective domain development is likely to apply to education all over the world, regardless of differences in races or nationalities.

\section{AFFECTIVE DOMAIN DEVELOP- MENT}

Richards \& Schmidt (2002:169) define affective domain as objectives which have as their purpose the development of students' attitudes, feelings and values, while Collins \& O'Brien (2003:12) consider affective domains as those aspects of learning that involve emotions, feelings and attitudes. Jalal 
(2010:11) relates affect and affective domain to spiritual or religious values when he suggests the integration of dzikir (prayers, remembering Allah - the One God) to fikir (mind, cognition) and psychomotor skill. This way, a man of character has the ability to balance the development of the cognitive, psychomotor, and affective forces. Hence, he will have enlightened conscience.

Citing Haigh (1975), Lang, Katz \& Menezes (1998:73) emphasize that the task of educators for children is 'more than filling empty buckets with knowledge'. In having both rights and obligations to respond to children's needs in the place of the parent, the teacher must necessarily be concerned with the affective domain. The significance of the affective for education is threefold. First, it is arguable that a concern to educate the whole child necessarily means a concern to educate the emotions (or 'affects') themselves. However, the teacher's role is most often associated with instruction in subject knowledge and the maintenance of discipline. Second, emotional states (and the values, attitudes, sensitivities, etc. which underpin or express them) may promote or impede the child's learning in other domains. It is necessary to address emotional matters in order to promote learning within the curriculum. Third, schools are institutions for socialization. The relationship between affects and moral values, successful social integration and effective interpersonal relations is powerful. In order to achieve the dual aims of social integration and personal development, schools must necessarily address the affective dimension of personal and social adaptation.

Specifically talking about character education, Foerster (Kholis, 2010:50) suggests four characteristics which are relevant to the nurturance of affective domain development. These four characteristics are: (1) consistency in the values used as normative reference to all actions pertaining to the given values; (2) coherence that encourages one to stick to the principles even if there are attached risks; (3) autonomy in internalizing the principles until they become personal values without any external compelling force; and (4) persistence and loyalty. In further details Megawangi (2010:30) asserts that education should lead to a healthy and happy family as indicated by the possession of the following characteristics: (1) the love of God and God's creation;(2) responsibility, discipline and autonomy; (3) honesty; (4) respectfulness and politeness; (5) affection, care and cooperation; (6) self-confidence, hard work and persistence; (7) justice and leadership; (8) virtue and humbleness; and (9) tolerance, peacefulness, and unity. In order to achieve the above characteristics, changes should start from every individual through internal transformation. This will happen only if one has the love of doing the good in this world. The love of doing the good is possible if one has the ability to distinguish the good from the bad. The love of doing the good, then, becomes a habit. This habit does not grow from drilling but starts from internal transformation due to understanding so that one develops (1) the 
habit of the mind; (2) the habit of the heart; and (3) the habit of the hands.

\section{PROBLEMS: GAPS BETWEEN REA- LITY AND EXPECTATION}

Vision and mission of almost every educational institution regard the development of affects as an important element in developing the young generation into the whole persons. The importance of the affective domain development is sometimes written not only in the curriculum or the institution's strategic development plan, but it may also be materialized in the form of slogans printed on souvenirs, banners, or even campus gate or the entrance to the institution's main office. Some schools even paint the slogan in big capital letters on the wall "TAQWA, CERDAS, TERAMPIL" (devout, intelligent, and skillful). The word "TAQWA" (devout) placed at the first position in the slogan must not have come by chance. The author must have thought of the primacy of the moral and spiritual values which are closely related to the affective domain.

In this regard, the Indonesian Police must also have realized the primacy of affects so that two of their slogans say "Polisi Sahabat Rakyat" (The Police are the People's Friends) (Rahardjo, 2002: 199) and "Polisi Sahabat Anak" (The Police are the Children's Friends) (Tabah, 1991:70). The Indonesian police want to build the public image that they are not merely oppressive law enforcers, but are also the partners of the public whenever a need arises.

The slogans above have been an eye-catching means of exposing the affection the respective institutions want the public to know. Besides, honesty, justice, empathy, self-sacrifice, dedication, tolerance, peace and harmony have been the topics people constantly watch and hear being preached live in mosques and churches or on television almost every day. Hence, affection should have developed accordingly in the heart of every individual and guided the dayto-day life of the Indonesian community. In reality, however, what happens is the opposite.

In the bureaucratic setting, corruptions flourish throughout the country (Sudarto, 2010), and legal abuses are part of day-to-day news hits. Irawan (2010) also cites Presiden Susilo Bambang Yudoyono's concern about the multitude of the government officials who are involved in corruption. He has given permits for over 150 government officials to be investigated due to their involvement in corruption cases.

In the parliamentary setting, shameful scenes can also be witnessed in almost every plenary meeting in which many members of the People's Representatives are caught sleeping. In some plenary sessions, many of the seats are vacant, indicating that many of the members are absent. Their children at home can see what they are doing for the big salary they receive out the people's money. An unpleasant scene was vulgarly demonstrated in therespectable forum of this respectablebody when members representing an opposition party protested the decision made by the chairman to stop the session discussing the issue of corruption related to Century Bank. Physical contacts between members of 
the People's Representatives werebroadcast live on TV (Boy M., 2010), while the discussion remained inconclusive.

The unsettled issues related to corruptions and legal abuses which were kept floating were felt by some to hurt the justice of the public. Some people doubt whether members of the People's Representatives actually represent the public aspiration. Pong's action of making a graffiti "JUJUR, ADIL, TEGAS" (honest, fair, firm) on the roof of the Indonesian Parliamentary Building was a reflection of his strong protest against the members of the People's Representatives who, in his view, did not represent the public who demanded honesty, fairness and firmness in dealing with parliamentary issues they were confronted with (Kristanti, 2010).

In the New Order era, indoctrination of "Pancasila" (the Five Principles, the Indonesian Way of Life) was carried out intensively and extensively all over Indonesia, including the remote rural areas. Millions and millions of dollars were spent and thousands and thousands of instructors were employed. However, the goodness of Pancasila only stopped at the rhetorical level as many of the key figures in the executive and legislative bodies failed to set examples as models of the implementation of the Pancasila as a way of life. The socialization of "sacred" Pancasila became an entertaining project of "clown" presentation, in which applauses would be echoing in the classroom if the presenter was able to cunningly throw cynical jokes to criticize one of the local or national key figures. Recently, similar dramas have been staged in more vulgar manners by many of the "respectable" key figures of the Indonesian community. The fight between members of the People's Representatives in the general assembly forum is an example of disharmony and ethical infringement (Boy, 2010). Another example is the news report that a number of members of the People's Representatives and high-ranking officials in different sectors of the government have been involved in corruption (Irawan, 2010). These ethical infringement and corruption were published in mass media nationally and internationally, so that not only our neighboring nations but people all over the world are exposed to the news.

As a result, Pancasila, which makes the foreign nations set a high esteem on the Indonesian people, has been slowly neglected due to the lack of exemplary models of its application in the realm of the Indonesian life (Sudarto, 2010:2). Ultimately, there is nothing to be proud of in this beloved country. There is no more clear reference as to what the government plans to do in order to correct the uncertainty of the people's way of life and to which direction the Indonesian people will be brought. Even when the idea of character education was launched by the Minister of National Education (Pena Pendidikan, 2010), the problem will lie on the lack of exemplary figures from the national to local and institutional levels who can set examples on the implementation of the character expected.

Inthe community setting, fights happen repeatedly between local residents, between residents of the neighboring villages, between incumbents of different 
political parties or supporters of different candidates in the election of governors or regents, and between supporters of the opposing teams in sports competitions. Children abuses and sexual harassments are frequently reported. Drug abuses, which were initially known only among the children of the rich and the middle or high class, are now penetrating those of the low social class as well. There have been sons killing their fathers with their own hands (Efti, 2003: 16), and a father raping his own daughter (Prakuso. 1989:83).

In the education setting, clashes often happen among university students (Saputra \& Zuula, 2010) or school children from the same or different schools. Despite restrictions from the management of the educational institutions, bullying is still practiced by the organizing committees of the new student orientation program. During the orientation program, some senior students abuse and even torture the freshmen.

In the case of affective domain development in education, ambivalence can also be felt in the assessment of the learners' success indicators. Despite the intention to place equal weighting on the learners' achievement in regard to the development of their cognitive, psychomotor and affective domains, the learners' success in the first two domains seems to blur the objective assessment on the last domain. Although evidence still needs to be collected, it seems that an SMA (Senior High School) student's success in the National Final Examination will be likely to positively influence his standing in the classroom despite his less successful achievement in the affective domain, i.e., moral development. The student's less successful achievement in the moral development may not be exposed unless this same student fails in the National Final Examination.

As the most important requirement for the enrolment to the higher education institution is the certificate of passing the National Final Examination, there is no legal filter which can prevent a certificate holder from moving on to the higher level of education. Meanwhile, those who excel in affective domain development but fail in the National Final Examination will have to lose the opportunity to move up.

A similar phenomenon may apply to the awarding of scholarships. So far, most scholarships are awarded to university students based on two criteria: academic achievement as indicated by cumulative achievement index or Grade Point Average (GPA) and economic status as proven by the statement of family's economic status stamped by the local authority. The higher achievers announced during the graduation ceremony are also based on the cumulative achievement index. Likewise, students who win sports competitions at the institutional, local, regional, national, or international level will always receive material or spiritual rewards. However, there may be few students, if any, who get formal or material rewards because of their being successful achievers in affective domain development. Proper behaviors require honesty, politeness, helpfulness, tolerance, respect towards elders and others, and piety. In practice, 
no formal recognition can be awarded to students possess all these capacities.

This ambivalence seems to be one of the reasons for the problems of the implementation and reinforcement of, and hence, the affective domain development in the educational setting. The children hear people preaching virtues, but in practice they witness vices both live and recorded and broadcast on mass media in their day-to-day living. Little is heard about those practicing virtues.

\section{A WAY OUT: ALTERNATIVES TO CORRECT THE CONDITION}

In Australia, up to 2001 (it may still be continued up to now), especially at the primary education level, the development of affects was emphasized, in everyday life, in line with the cognitive and motor skill domains. As an example, in Glenferrie Primary School, in the District of Hawthorne, the State of Victoria, pupils' success was assessed not only through the performance in the classroom in regard to their achievement in the course subjects such as natural science, language, or social science, but also through their attitudes and behaviors observed outside the classroom, or even outside the school.

Atthis school, a ceremony was carried out in the school hall every Monday morning before classes started. The ceremony was attended not only by the pupils and the teachers but also by the parents who drive or walk the children to the school. The school principal would give a speech concerning the school program for the week to come and report what the school had achieved within the past week. The principal would not saya word before the audience was completely silent. At the end of his speech came a moment for which everyone was waiting.

One of the pupils (selected from a different class every week) stood up in the middle of the crowd and announced the names and the achievements of the pupils of the week followed by the presentation of the certificates by the school principal accompanied by one of the school teachers. The certificates were awarded to pupils who excelled in a sports or music competition and those who demonstrated outstanding performance in a number of subjects such as mathematics, foreign languages, arts, etc. Interestingly, the awards were also given to pupils who might not have excelled in cognitive and motor skill domains but had clearly indicated the well-developed affective factors.

For example, an award was given to (1) a pupil who almost always helped the classroom teacher to carry the books and other stuff to and from the classroom; (2) a pupil who was most attentive in listening to the presentation given by the librarian at the District Library; (3) a pupil who was most attentive and helpful to the juniors when she was assigned to assist the classroom teacher in one of the lower level (junior) classes (It was customary at the primary school for Grade 5 and 6 pupils to assist the teachers in Grade 1, 2, or 3 classroom); (4) pupils who were observed voluntarily helping parents and juniors to cross the road in front of the school building; and (5) a pupil who had saved another pupil who almost became a victim of an accident on the playing ground. Has 
any school or educational institution in Indonesia appreciated the development of pupils' affective domain in such a way?

In stressing the importance of rewards in education, Lewis (2010) recognizes that rewards and punishments are part of a controversial topic for teachers. Many teachers see extrinsic material rewards as an appropriate and effective way to manage behavior in the elementary classroom. Other teachers don't want to "bribe" the kids to do work that they should be intrinsically motivated to do on their own. To avoid or minimize dependency of the children on the material value of the rewards, Lewis suggests the following:

The idea of classroom rewards is an important concept to consider in the beginning of the school year. If you start off the year showering students with rewards, they are going to expect it and will most likely only work for the rewards. However, if you limit prizes from day one, you may find that you can get away from the material aspect a little bit and save yourself a significant amount of money in the long run.

The controversy about the use of rewards above seems justified as prolonged use of rewards may motivate the children to work for the rewards only. They may lose the spirit of learning to shape their capacity, to prepare themselves as autonomous individuals. In regard to the Indonesian concept of education, children have to develop their potentials into individuals who believe in, and devote life to, the One God, have high morals and good health, are knowledgeable, intelligent, creative and autonomous, and become democratic and responsible citizens (Department of National Education of the Republic of Indonesia, 2003: 11).

Rewards as a means of motivating the affective domain development in the context of educating should be given wisely. They are not always given in the form of material rewards, but recognition on a learner's performance that indicates the affective domain development should be directly or indirectly shown to the learner. Direct recognition can be in the form of a word of praise such as "Good!", “Keep it up!", “Thanks!”, etc. Indirect recognition can be in the form of closeness or intimacy upon noticing a virtue a learner has done. The virtue may be as simple as saying "Good morning!" or can be as serious as organizing fund-raising in secrecy intended to help a student who is unable to pay for the tuition for a certain semester. The "TOLONG" (HELP) program on RCTI Television Station can be used as a model to motivate learners of various age levels to have concern on the suffering of other people. A similar program can be conducted by a school management team to nominate or select several students as exemplary figures. Further selection processes can be carried out to decide in secrecy one or two learners who deserve a reward from the school.

There are private schools, especially religion-based schools in Yogyakarta, which have practiced what they preach. For example, in one of these schools, every morning, as the pupils arrive, the school principal and the teachers line up in front of the gate to greet the pupils by shaking hands with them. 
Other than greeting the pupils, the principal or the teachers also check whether they are already properly dressed, or whether they have clean, short-cut fingernails. As parents taking the children to the school witness this happen every morning, it is not difficult for them to agree that the school principal and the teachers are really practicing what they are preaching. In turn, the teachers also see that most of the pupils say goodbye to their parents who drop them at the school gate by kissing their hands.

This particular school has three-storey buildings. Near the staircase of each floor there is usually a teacher who reminds the pupils to set the right foot first when going upstairs and the left foot first when going downstairs, as exemplified by the Moslem teaching. This and the above practices are all intended to nurture the application of the affective and spiritual or moral values in the day-to-day living at school as well as home. In spite of this, there has been no explicit reward given to successful achievers such as those awarded to pupils of the week at Glenferrie Primary School.

The government of Jeneponto Regency held "Festival Anak Shaleh" (Pious Children's Festival) on Friday, 23 July 2010. Syamsuddin, Head of the Public Relations Office of Jeneponto Regency explained that the festival was intended to motivate the children in the area to express and appreciate themselves. As the young generation who would be future leaders they had to get moral nurturance other than formal education at school. The children joining the festi- val could also share their experiences, struggles, sadness and happiness in their study at different types of educational institutions in which they developed tolerance, respect towards others, etc. The government expected that through the festival both the participants' affective and moral or spiritual qualities would develop.

A similar festival was earlier conducted in Purbalingga (Soetarto, 2004) to nurture the spirit to love the Quran so that the children will grow into a Qurani generation (a generation practicing the teaching of the Quran). The festival tried to combine the teaching of religion with that of culture and arts. This way, children would not only hear what the teacher and people say, but they could see and do something, actively participating in the series of activities in the festival. Soetarto suggested that by hearing and seeing children would absorb (learn) $30 \%$ of the information or knowledge, while by doing they would understand $70 \%$ of what theywere learning. If these different methods of learningwere combined, children would learn more than $100 \%$.

These festivals, which demand the participants' totality in using all their potentials they have developed, including cognitive, psychomotor skill and affective domains, give the children more opportunities to express themselves. These activities and other efforts made by the schools mentioned earlier should be adapted as models for other schools, both private and public ones.

Khisbiyah (2010:11) suggests that a more effective means of developing affective domain should be through the 
presence of exemplary models or role modeling. Through role modeling, with little or no preaching, children will easily model themselves to their idols. In line with this suggestion, Lapsley \& Narvaez (2004:67) assert that moral identity emerges from the opportunities offered by social relationships and institutions to observe, experiment with, and receive support for the enactment of moral action. Oftentimes those with well-developed moral identities are contrasted withmembers of the general public, focusing on the formers' ability to pursue moral goals that are inconsistent with the societal norms judged to orient the latters' actions. For example, people think of Ghandi's rejection of materialist values of many of his countrymen in order to pursue his goals for civil justice. While it is certainly true that moral identities can sustain moral behavior in social contexts that do not support such behavior, this does not mean that moral identities are formed independent of social contexts. Indeed, virtually all biographies of morally exemplary individuals document the role of particular relationships and specific institutions on moral commitment.

In the family, parents should set good examples for their children by involving children in working bees and collecting alms for public causes. Children need to see examples that helping each other and working not only for their own benefit are virtues they should model. Parents need to ask them to deliver alms or contribution to the mosque nearby the house, give money to the beggars, serve the drink to the guests, etc. Such practices will have great impact on their life when they come to be adults. They will have sympathy on the needy and share part of their welfare for the public causes.

In efforts to aid the children's affective domain development, Djohantini (2010:11) stresses the need for mentoring. Parents have to update their knowledge, including that of the latest development in information and communication technology (ICT), so that they can guide and nurture members of the family who are still in the process of maturing. This is particularly true to living in this technology era.

The gap in technology such as the inability of parents to understand a "simple" technology of using a mobile phone may result in the family disaster as parents are unable to control whatever the children are doing with their mobile phones. The availability of all kinds of information and the facilities to access the information enable children to download internet materials which are relevant to their age and studies as well as those which may endanger their minds and affects. They can easily access pornographic sites which may lead them to inability to concentrate on their study. Worst of all, there were rape cases reported to happen after the adolescent rapists had watched pornographic movies (Iswarahadi, 2003:74).

\section{CONCLUSION}

Ambivalent practices, which show the distinct gap between words and actions, such as witnessed in the permissive treatment, or even nurturance of corruption practices involving government officials as well as members of legis- 
lative bodies who often preach religion, may result in the degradation or the absence of the values of justice, honesty, and accountability, which are elements of affect. Moral and spiritual values may also be blurred by the appearance of seemingly respectable figures of high morals but turning out to be unrespectable in their day-to-day living realities. Children often witness examples of vulgar scenes on television contrary to the refined conducts they are told by the teachers at school or by the parents at home. What is needed by these children are exemplary models anywhere they go so that they can see and feel consistency in the values used as normative reference to all actions pertaining to the given values as suggested by Foerster. Besides, as children are still in the process of development and trying to find the self-identity, mentoring is required. Parents should always update themselves with practical knowledge such as the use of mobile phones so that they can control or check what their children do with their mobile phones in order to make sure that the modern technological facilities will aid, not hinder, the development of the affective domain in a positive manner and the habit formation of doing good. While children often witness the presentation of rewards to successful cognitive and psychomotor skill domain achievers, chances should also be available in which they can see, feel, and experience the rewards actually given to those who excel in the development of affective domain. This way, the children will be able to model words that have come into actions.

\section{UCAPAN TERIMA KASIH}

Terima kasih saya ucapkan kepada Dewan Redaksi Jurnal Cakrawala Pendidikan, terutama Prof. Dr. Burhan Nurgiantoro, atas dorongan yang diberikan untuk memasukkan draft awal dan kepada Redaktur Penyelia atas saran demi perbaikan artikel ini. Terima kasih juga saya sampaikan kepada Staf Jurnal Cakrawala Pendidikan Universitas Negeri Yogyakarta atas kesabaran dalam layanan sehingga artikel ini dapat masuk dalam edisi penerbitan ini.

\section{REFERENCES}

Boy M. 2010. “Makna Ketok Palu Ketua DPR Marzuki Alie" from http:-Lwww.jakartapress.com/wwww.php/ne ws/id/11892/Makna-Ketok-Palu-Ketua-DPR-Marzuki-Alie.jp. Accessed 17 July 2010.

Collins, J.W., O'Brien, N.P. 2003. The Greenwood Dictionary of Education. London: Greenwood Press.

Departemen Pendidikan Nasional Republik Indonesia. 2003. UndangUndang Republik Indonesia Nomor 20 Tahun 2003 tentang Sistem Pendidikan Nasional. Jakarta: Biro Hukum dan Organisasi, Setjen Depdiknas.

Djohantini, Siti Noordjanah. 2010. “Ibadah Terjermin dalam Muamalah". Suara Muhammadiyah, XCV (18), 11.

Efti. 2003. "Anak Membunuh Ayah Kandung". Suara Aisyiyah LXXX (1-12), 16. 
Irawan, Ade. 2010. “Pejabat Banyak Korupsi, SBY Prihatin" from $\underline{h t t p-}$ ://klikp21. com/hukumnews/9162-pejabat-banyak-korupsi-sby-prihatin. accessed 20 August 2010.

Iswarahadi, Y. I. 2003. Beriman dengan Bermedia - Antologi Komunikasi. Yogyakarta: Penerbit Kanisius.

Jalal, Fasli. 2010. "Padukan Pikir dan Zikir". Suara Muhammadiyah XCV (18), 11.

Khisbiyah, Yayah. 2010. "Karakter Bangsa Terbentuk dari Karakter Warganya". Suara Muhammadiyah, XCV (18),11.

Kholis, Nur. 2010. “Keluarga sebagai Pilar Pendidikan Karakter". Suara Muhammadiyah XCV (17), 50.

Kristanti, Aryani. 2010. Aksi Pong: Rakyat Tersakiti Ulah Anggota DPR. http:/wwww.tempointeraktif.com/ hg/politik/2010/07/30/brk,2010073 0-267679,id.html. Accessed 2 August 2010.

Lang, P., Katz, Y. \& Menezes, I. (eds.). 1998. Affective Education: A Comparative View. New York: Cassell.

Lapsley, Daniel K. \& Narvaez, Darcia, (eds). 2004. Moral Development, self, and identity. New Jersey: Lawrence Erlbaum Associates, Inc.

Lewis, Beth. 2010. “Should You Offer Extrinsic Classroom Rewards for Good Behavior?" from http://k6educators.about.com/cs/classroom manageme3/al rewardsprizes.htm. Accessed 13 August 2010.

Megawangi, Ratna. 2010. “Pembentukan Insan Berkarakter Harus Simultan". Suara Muhammadiyah Suara Muhammadiyah XCV (17), 28-30.

Ministry of National Education of the Republic of Indonesia. 2003. Indonesian Education Act No. 20 Year 2003 on the National Education System. Jakarta: Author.

Prakuso, Bambang. 1989. Kasus Kejahatan Seks: Hukum atau Keadilan? Jakarta: Antar Kota.

Rahardjo, Satjipto. 2002. Membangun Polisi Sipil - Perspektif Hukum, Sosial, dan Kemasyarakatan. Jakarta: Penerbit Buku Kompas.

Richards, Jack C. \& Schmidt, Richard. 2002. Longman Dictionary of Language Teaching and Applied Linguistics. (3rd ed.) London, New York: Pearson Education Limited.

Saputra, Arwan Ganda \& Zuula, Asdar. 2010. "SK Rektor Berbuah Bentrok Antar-mahasiswa". From http://berita.liputan6.com/daerah/20 1002/264047/SK. Rektor. Berbuah.Bentrok.Antarmahasiswa. accessed 20 July 2010.

Sudarto, Tyasno. 2010a. "Perlu Revolusi untuk Berantas Korupsi Merajalela". From http:// www.antaranews.com/berita/1266276347/tyasno -perlu-revolusi-untuk-berantas-ko- 
rupsi-merajalela/2010/02/16.

Accessed 11 July 2010.

2010b. "Pancasila sebagai Way of Life Semakin Kabur". Kedaulatan

Rakyat, 26 September 2010, p. 2.

Syamsuddin. 2010. “Jeneponto Gelar Festival Anak Shaleh Jumat, 23 Juli 2010." From http://www.antara-sulawesiselatan.com/berita/17172/jeneponto-gelar-festival-anakshaleh. accessed 14 August 2010.

Tabah, Anton. 1991. Membangun POLRI yang Kuat: Belajar dari Macanmacan Asia. Jakarta: Mitra Hardasuma. 